\title{
Taxing the Financially Integrated Multinational Firm
}

Johannesen, Niels

Publication date:

2010

Document version

Publisher's PDF, also known as Version of record

Citation for published version (APA):

Johannesen, N. (2010). Taxing the Financially Integrated Multinational Firm. Department of Economics, University of Copenhagen. 
Economic Policy Research Unit

Department of Economics

University of Copenhagen

$\emptyset$ ster Farimagsgade 5, Building 26

DK-1353 Copenhagen $K$

DENMARK

Tel: (+45) 35324411

Fax: (+45) 35324444

Web: http://www.econ.ku.dk/epru/

Taxing the Financially Integrated Multinational Firm

Niels Johannesen 


\title{
Taxing the financially integrated multinational firm
}

\author{
Niels Johannesen \\ Department of Economics, \\ University of Copenhagen
}

July 2010

\begin{abstract}
This paper develops a theoretical model of corporate taxation in the presence of financially integrated multinational firms. Under the assumption that multinational firms at least partly use internal loans to finance foreign investment, we find that the optimal corporate tax rate is positive from the perspective of a small, open economy. This finding contrasts the standard result that the optimal source based capital tax is zero. Intuitively, to the extent that multinational firms finance investment in country $i$ with loans from affiliates in country $j$, the burden of corporate taxes in the latter country partly fall on investment and thus workers in the former country. This tax exporting mechanism introduces a scope for corporate taxes, which is not present in standard models of international taxation. Accounting for the internal capital markets of multinational firms thus represents a way to resolve the tension between standard theory predicting zero capital taxes and the casual observation that countries tend to employ corporate taxes at fairly high rates.

Keywords: Corporate taxation, Tax exporting, Multinational firms, Internal capital markets,
\end{abstract}

\section{Introduction}

Multinational firms account for a large and increasing share of world output and have been the object of much recent research. Key insights concern the multiple purposes served by internal capital markets. Firstly, several papers demonstrate that internal capital markets may substitute for dysfunctional external capital markets. For instance, there is evidence that multinational firms extend more internal loans to foreign affiliates in countries with weak creditor rights where the cost of external loans is higher (Desai et al., 2004). Also, it has been shown that internal capital markets allow affiliates of foreign multinationals to expand in the aftermath of currency crises where local firms are constrained by scarce external financing (Desai et al. 2007). Secondly, a series of papers point to the role of internal capital markets as a profit shifting instrument. Specifically, it has been shown that multinational firms provide more internal loans and less equity to foreign affiliates when the corporate tax rate facing the foreign affiliate is high (Desai et al., 2004; Buettner et al., 2009). Finally, it has been argued that internal capital markets serve to mitigate disadvantages associated with the multinational organizational form. For instance, there is 
evidence that profitable foreign affiliates of US multinationals provide capital directly to other foreign affiliates, which allows for a deferral of the US tax on repatriations to the parent company (Altshuler and Grubert, 2002).

Importantly, internal capital markets give rise to financial linkages within the multinational firm in the sense that the different entities of the firm are tied together by internal loans and equity stakes. A detailed dataset on German inbound and outbound foreign direct investment collected by the German Central Bank provides a rare opportunity to assess the nature and size of these financial linkages. For a sample of German multinational firms, Buettner and Wamser (2009) report an average 'internal debtasset ratio' of foreign affiliates of around $25 \%$. Roughly half of the internal loans was granted by German parent companies whereas the remaining half was provided by other foreign affiliates. As shown in the next section, these figures are largely consistent with available data on the capital structure of US and other multinationals.

This paper develops a model of capital taxation in the presence of financially integrated multinational firms. The model makes two key assumptions. Firstly, it is assumed that multinational firms at least partly use internal loans to finance foreign investment. This assumption is in line with the empirical evidence on the capital structure of multinational firms, which suggests that internal loans typically finance $25-30 \%$ of the assets of foreign affiliates. Secondly, it is assumed that internal loans serve other purposes than profit shifting. This assumption is consistent with the empirical literature on internal capital markets, which identifies several important motives for internal financing unrelated to profit shifting. It is also supported by the fact that German parent companies provide foreign affiliates with a substantial amount of internal loans. As noted by Buettner and Wamser (2009), these loans cannot be rationalized within a profit shifting framework since the German corporate tax rate is very high by international standards.

The main finding of the paper is that internal loans introduce a tax exporting mechanism that causes the optimal corporate tax rate to be positive from the perspective of a small, open economy. This contrasts the standard result that the optimal source based capital tax is zero (Gordon, 1986). In the standard model with only domestic firms, small, open economies are facing a perfectly elastic supply of capital, hence the entire burden of capital taxes is shifted to domestic workers. By distorting the labor supply to the same extent as labor taxes and adding a distortion of the capital-labor ratio, capital taxes are thus strictly dominated by labor taxes. In our model, multinational firms operate in two countries $A$ and $B$ and partly finance affiliates in country $A$ with internal loans from affiliates in country $B$. As in the standard model, taxes raising the cost of investment in country $A$ are fully shifted to workers in this country. However, under the usual rules of corporate taxation with full deduction for interest expenses and full taxation of interest income, the internal loans shift tax base from country $A$ to country $B$ and the effective tax rate on investment in country $A$ is thus partly determined by the corporate tax rate in country $B$. Hence, by raising the effective tax rate on capital in country $A$, corporate taxes in country $B$ are partly exported to workers in country $A$. This provides a motive for using capital taxes in country $B$, which is absent in the standard model. 
Our finding may be reconciled with the standard result that the optimal source based capital tax is zero by noting that in the presence of intra-firm financial linkages the corporate tax is no longer a pure source tax. Since investment is partly financed with internal loans from entities located in other countries, the tax base generated by investment in any given jurisdiction is effectively shared between several jurisdictions.

By accounting for the internal capital markets of multinational firms, our model resolves the tension between the standard result that the optimal source based capital tax is zero and the casual empirical observation that most countries employ corporate taxes at fairly high rates. A number of alternative explanations have been put forward to explain the fact that countries raise considerable revenue with source based capital taxes. Wildasin (2003) shows that under imperfect capital mobility, optimal capital taxes are positive and inversely related to the speed with which the capital stock adjusts in response to changes in the local return to capital. Gordon and MacKie-Mason (1994) argue that income shifting between different tax bases introduces a scope for using a capital income tax since the latter works as a back-stop for the personal income tax. Gordon and Varian (1989) show that country-specific productivity shocks resurrect the case for positive capital taxes because the desire of foreign investors to hedge risk implies that the demand for domestic capital is imperfectly elastic with respect to the net-of-tax return.

A few existing papers analyze capital taxation in the presence of financially integrated multinational firms while focusing exclusively on financial strategies that allow multinational firms to shift corporate tax base between jurisdictions. Huizinga et al. (2008) present a model of debt shifting where multinational firms - like domestic firms - choose the optimal leverage by trading off agency costs against tax benefits but - unlike domestic firms - are able to allocate more debt to subsidiaries facing high corporate tax rates. Other papers develop models of profit shifting where internal loans from affiliates in tax havens to other affiliates reduce the global tax liabilities of the multinational firm (Fuest and Hemmelgarn, 2005; Johannesen, 2010). Generally, tax motivated financial strategies like debt shifting and profit shifting tend to increase the tax sensitivity of capital tax bases and reinforce the race-to-the-bottom in capital tax rates. The present paper shows that the use of non-tax motivated financial strategies may generate just the opposite result.

Finally, the tax exporting mechanism, which is at the heart of the model, relates our work to Huizinga and Nielsen (1997). The key assumptions of the latter paper are foreign ownership of firms and existence of pure economic rents. Under these assumptions, taxes on the normal return to capital are partly shifted to foreign owners of domestic firms through a reduction in rents. Clearly, this is akin to our model where capital taxes are partly shifted to foreign workers through a reduction in foreign wages.

The remainder of the paper is structured as follows. Section 2 discusses the use of internal loans within multinational firms. Section 3 develops a model of optimal capital taxation in the presence of financially integrated multinational firms. Section 4 presents an extended model with endogenous financial structure. Section 5 presents a crude empirical test of the model. Section 6 concludes. 


\section{The use of internal loans by multinational firms}

Internal loans play a crucial a role in our model. This section therefore provides a thorough discussion of the use of loans within multinational firms. Firstly, we briefly review existing empirical evidence on the size and structure of internal loans. Secondly, we offer some explanations for the apparent puzzle that firms in many cases resort to internal loans although equity investments would be more favorable from a corporate tax perspective.

The leading empirical evidence on the capital structure of multinational firms is summarized in Table 1. The MiDi dataset collected by the German Central Bank is a unique data source containing very detailed financial information on virtually all German inbound and outbound foreign direct investment since 1996. Two recent papers provide summary statistics from this dataset. Buettner and Wamser (2009) report an average 'internal debt-asset ratio' of foreign affiliates of German firms of around $24 \%$. The 'internal debt-asset ratio' is decomposed into a 'parent debt-asset ratio' of $13 \%$ and an 'other affiliate debt-asset ratio' of $11 \%$. Ramb and Weichenreider (2005) report an average 'internal debt-asset ratio' of German affiliates of non-German firms of around 29\%. Two papers provide evidence on the use of parent debt by US multinational firms using two distinct data sources. Altshuler and Grubert (2002) report an average 'parent debt-asset ratio' of foreign affiliates of around $11 \%$ based on data collected by the US Internal Revenue Service. Desai et al. (2004) report a slightly lower average 'parent debt-asset ratio' of around 9\% drawing on a dataset from the US Bureau of Economic Analysis. The US data sources do not distinguish between loans from other affiliates than the parent company and loans from third parties and, hence, do not contain sufficient information to compute the total 'internal debt-asset ratio' of foreign affiliates.

This empirical evidence lends strong support to the two key assumptions of the theoretical model to be developed in the next section. Firstly, the model assumes that internal loans play a significant role in financing cross-border investment. The two papers reporting average 'internal debt-asset ratios' on the basis of microdata find that internal loans account for as much as $25-30 \%$ of the financing of foreign affiliates. ${ }^{1}$ Secondly, the model assumes that internal loans are not exclusively motivated by profit shifting in the sense that even if the corporate tax rate in country $i$ is (moderately) higher than the corporate tax rate in country $j$, some entities in country $j$ receive loans from affiliates in country $i$. This assumption is clearly consistent with the empirical evidence since parent companies in both Germany and the US are important providers of internal loans to foreign affiliates despite the relatively high corporate tax rates in these countries. ${ }^{2}$

\footnotetext{
${ }^{1}$ This finding is also consistent with macrodata. In the sectoral breakdown of national accounts, the external loans of multinational firms generally appear as interest expenses in the non-financial corporate sector whereas internal loans appear both as interest income and interest expenses. According to Eurostat, the interest income and interest expenses of non-financial corporations resident in the EU amounted to $€ 280$ billion and $€ 470$ billion respectively in 2007 . The fact that interest income amounts to almost $60 \%$ of interest expenses is suggestive of an important role for internal loans.

${ }^{2}$ Another finding indicating that internal loans serve other purposes than profit shifting is due to Gopalan et al. (2007) who document large flows of internal loans within Indian business groups. Clearly, such flows do not have a profit shifting motive since the borrowing and lending entities face the same corporate tax rate.
} 
While the German and US data provide strong evidence that firms use internal loans for other purposes than profit shifting and this finding is consistent with the literature on internal capital markets stressing the non-tax motives for intra-firm capital flows, the prevalence of internal loans from parent companies in high-tax countries to affiliates in low-tax countries represents a puzzle in the sense that internal loans are dominated by equity investments from a corporate tax perspective. Loans from a parent company in a high-tax country to an affiliate in a low-tax country transfers taxable profits from the low-tax to the high-tax country. Alternatively, the parent company could provide funds in the form of equity, in which case the full investment return would be subject to corporate taxation in the low-tax country. It is not immediately clear why firms in many cases choose the mode of financing associated with the larger corporate tax burden. In the remainder of this section, we explore a number of explanations for this puzzle.

Chowdry and Coval (1998) present an explicit treatment of the choice between internal debt and equity within multinational firms. The paper models a parent company financing a foreign subsidiary with either internal debt or equity in an environment with uncertainty about future earnings. The main finding is that under a typical corporate tax system with imperfect carry-forward of tax losses, the optimal capital structure involves a mix of internal debt and equity. Intuitively, the possibility that the parent company will be loss-making in future periods introduces an incentive to use debt financing even when the parent company faces a higher corporate tax rate than the subsidiary since interest income at the level of the parent company in some states of the world are shielded by losses. Similarly, the possibility that the subsidiary will be loss-making in future periods limits the incentive to use debt financing even when the parent company faces a lower corporate tax rate than the subsidiary since interest expenses at the level of the subsidiary in some states of the world do not shield profits.

Another strand of literature that may shed light on the choice between internal debt and equity focuses on the principal-agent problems inherent to the corporate organizational form where managers (agents) conduct business on behalf of shareholders (principals). Jensen (1986) argues that if managers are self-interested and tend to engage in empire building, debt may increase efficiency by reducing the free cash flow available for unprofitable investment. While the original formulation of the theory is concerned with the merits of external loans, a similar reasoning may arguably be applied to internal loans. Within the multinational firm, local managers of foreign subsidiaries (agents) conduct business on behalf of the central management of the firm (principal). Assuming that local managers tend to be concerned with the growth of the specific subsidiary that they operate whereas the objectives of the central management relate to the performance of the entire firm, financing in the form of internal loans represent an instrument to prevent excessive growth in subsidiaries with a large cash flow. Moreover, interest payments specified ex ante in a loan agreement are arguably a superior means to achieve this end than dividend payments decided ex post on the basis of available accounting profits, the size of which is at least partly controlled by the local management.

Less theoretically founded but nevertheless potentially important explanations for the prevalence of internal loans revolve around the fact that loans constitute a flexible and cost efficient way to transfer 
funds within the firm.

Firstly, from a corporate law perspective, debt is a much more flexible financial instrument than equity. When a parent company injects capital into a subsidiary in the form of equity, a number of formal requirements must be observed. The legal details vary across countries, however, typically a decision to issue new shares must be adopted by the general assembly or the board of directors of the subsidiary, the decision needs the attestation of a notary public, the statutes of the subsidiary must be modified to reflect the higher share capital of the firm and the new statutes of the firm must be published in the official gazette. Similarly, repatriation of profits in the form of dividends is subject to a number of legal requirements and restrictions. The decision to pay dividends must be adopted by the general assembly or the board of directors, interim accounts need to be drawn up and approved by an external auditor unless the distribution coincides with the closing of the annual accounts and dividends cannot be paid out of capital, reserves or unrealized profits. By comparison, debt finance is very straightforward. Essentially, the transfer of funds from one affiliate to another in the form of a loan merely requires that the managers of the two entities conclude a loan agreement, which also specifies the size and timing of the interest payments.

Secondly, other taxes than the corporate tax may influence the choice between financing with equity or internal loans. A number of countries levy capital duties, which are taxes on the transfer of capital to corporations in the form of equity. Currently, seven EU member states levy capital duties at rates ranging from $0.5 \%$ to $1 \%$ and similar taxes have only recently been abolished in a number of other EU countries. ${ }^{3}$ Capital transfers in the form of loans are not subject to capital duty, which constitutes a clear advantage of internal debt financing over equity financing. Also, cross-border dividends and interest payments may be subject to withholding taxes at differential rates. Although withholding taxes in the source country can often be credited against tax liabilities in the residence country, there are a number of instances where withholding taxes affect the level of effective taxation and thus influence the choice between equity or internal loans. ${ }^{4}$

Finally, when firms are organized with chains of ownership, as is often the case with large multinational firms, the two above mentioned disadvantages of equity financing are exacerbated. This is illustrated in Figure 1, which depicts the holding structure of a stylized multinational firm. The firm wishes to transfer funds from the profitable subsidiary E to the cash-strapped subsidiary F. To complete the transfer without the use of internal loans and without changes in the holding structure, funds need to pass along existing ownership chains, that is as dividend payments from $\mathrm{E}$ to $\mathrm{C}$, from $\mathrm{C}$ to $\mathrm{A}$ and from A to $\mathrm{P}$ and, then, as contributions of equity from $\mathrm{P}$ to $\mathrm{B}$, from $\mathrm{B}$ to $\mathrm{D}$ and from $\mathrm{D}$ to $\mathrm{F}$. Each step is

\footnotetext{
${ }^{3}$ European Commission (2006) reports that capital duties are levied at the rate of 0.5\% in Poland and Portugal, $0.6 \%$ in Cyprus and 1\% in Greece, Spain, Austria and Luxembourg. Moreover, capital duties were abolished in Ireland in 2005 and in Belgium and Netherlands in 2006.

${ }^{4}$ Huizinga et al. (2008) report that 31 (26) out of 32 European countries in their sample grant tax credits for foreign taxes paid on foreign source interest income when the source country is a treaty partner (non-partner). The relief for foreign taxes provided by tax credits is only partial when when the foreign withholding tax rate exceeds the domestic corporate tax rate and when the receiving company has no tax liabilities against which foreign taxes can be credited.
} 
associated with administrative costs and possibly tax costs in the form of withholding taxes on dividend payments or capital duties on contributions of equity. A loan from $\mathrm{E}$ to $\mathrm{F}$ achieves the same end as the chain of dividend payments and equity contributions but arguably at a lower level of administrative and tax costs.

\section{The basic model}

\subsection{Assumptions}

The model considers two countries $A$ and $B$. Each country is inhabited by a single representative agent endowed with $\bar{S}$ units of capital and $\bar{L}$ units of labor. We adopt the standard assumptions that capital is perfectly mobile across countries whereas labor is immobile. Both countries are small in the sense that policy decisions have a negligible impact on the required return to capital $r$ which is determined on international capital markets. The representative agent is characterized by the standard utility function $U(C, X, G)$ where $C$ is private consumption, $X$ is leisure and $G$ is public expenditure. We let $L$ denote labor supply and thus establish the following identity: $\bar{L}=X+L$. Firms produce according to the standard production function $F(K, L)$ with constant returns to scale. There is free entry of firms, hence firms earn zero profits in equilibrium.

Governments are benevolent and have access to two tax instruments: a tax on labor $t^{L}$ and a source tax on capital $t^{K}$. For expositional simplicity, we assume that taxes fall directly on production factors and not on the income they generate. The tax base of the labor tax is thus $L$. The tax base of the capital tax is $K$ reduced by financial liabilities and augmented by financial assets. Since firms earn no pure profits, the capital tax is equivalent to a standard corporate tax on profits net of labor costs and interest expenses. Importantly, we adopt the standard assumption that governments are unable to enforce a residence based capital tax, for instance, due to imperfect information about foreign source income.

The main departure from the standard model of tax competition is the introduction of multinational firms with stocks of intra-firm debt and equity. We assume that multinational firms consist of three types of entities: the parent company, subsidiaries operating production plants (i.e. 'operating subsidiaries') and subsidiaries holding financial assets (i.e. 'finance subsidiaries'). The financial structure has two distinct dimensions: the leverage of the firm as a whole and the intra-firm distribution of financial assets and liabilities. We let $q$ denote the debt-asset ratio of the firm as a whole and $s_{A}$ and $s_{B}$ denote the debt-asset ratio of operating subsidiaries in countries $A$ and $B$ respectively. We assume throughout the paper that $s_{A} \geq q$ and $s_{B} \geq q$, which imposes that operating subsidiaries are partly financed with internal debt. Firm allocate a fraction $z_{A}$ of the intra-firm debt claims to finance subsidiaries in country $A$ and a fraction $z_{B}$ to finance subsidiaries in country $B$ where $z_{A}+z_{B}=1$. Figure 2 illustrates the capital structure of a multinational firm. For each unit of real capital required in a operating subsidiary in country $i$, the parent company raises a fraction $(1-q)$ as equity in international capital markets. A fraction $\left(1-s_{i}\right)$ is injected into operating subsidiaries as equity. The remaining fraction $\left(s_{i}-q\right)$ is 
injected into the finance subsidiaries as equity in proportions given by $z_{A}$ and $z_{B}$ and passed on to the operating subsidiary as loans. Finally, the operating subsidiary raises a fraction $q$ as debt in international capital markets. For future reference, we define $\mathbf{s} \equiv\left(s_{A}, s_{B}\right)$ and $\mathbf{z} \equiv\left(z_{A}, z_{B}\right)$. The financial structure of a multinational firm thus characterized by the vector $(q, \mathbf{s}, \mathbf{z}) .^{5}$

The most crucial assumption embedded in this construction is that firms make use of cross-border internal loans. Specifically, it is implied that each unit of real capital in country $i$ is financed with a fraction $z_{j}\left(s_{i}-q\right)$ of loans from affiliates in country $j$. More technically, it is an important assumption that multinational firms based in countries $A$ and $B$ have identical financial structures. A 'home bias' in financial policies would change the nature of the policy game considerably. ${ }^{6}$

The remainder of the section analyzes the following two-stage game: In the first stage, governments set taxes so as to maximize the welfare of the representative agent while correctly anticipating behavioral responses of firms and individuals and taking the tax rates of other countries as given. In the second stage, the representative agents optimally choose their labor supply taking wages and the level of public expenditure as given whereas firms hire production factors and produce. Section 3.2 characterizes labor and capital market equilibrium in the second stage conditional on tax policies. Section 3.3 derives conditions for optimal policies. Throughout section 3, we impose the assumption that the financial structure of multinational firms is fixed. This simplification allows us to clearly expose the tax exporting mechanism, which is the key insight of the paper. Section 4 shows that under relatively mild assumptions the main result of the analysis carries over to an extended framework where the financial structure is chosen optimally and thus responds to changes in tax policy.

\subsection{Capital and labor market equilibrium}

We first consider the profit maximization problem of the multinational firm. Since this basic version of the model is holding the financial structure fixed, profits are simply maximized with respect to labor and capital inputs in the two countries:

$$
\max _{L_{A}, L_{B}, K_{A}, K_{B}} \pi=\sum_{i=A, B}\left\{F\left(K_{i}, L_{i}\right)-L_{i} w_{i}-\left(r+\tau_{i}\right) K_{i}\right\}
$$

\footnotetext{
${ }^{5} \mathrm{~A}$ feature of the financial structure that may seem peculiar is the exclusive use of finance subsidiaries for the holding of financial assets. While it is well-known that multinational firms rely heavily on specialized corporate vehicles for financial transactions, the empirical literature reviewed in section 2 showed that also parent companies are important providers of internal loans. In an equivalent formulation of the model, parent companies in country $i$ allocate a fraction $z_{j}$ of the debt claims on operating subsidiaries to a finance subsidiary in country $j$ and hold the remaining fraction $z_{i}$ itself.

${ }^{6}$ If, for instance, firms were identical except that firms based in country $i$ allocated a larger fraction of financial assets to finance subsidiaries in country $i$ than firms based in country $j$, the former firms would be more profitable than the latter if $t_{i}^{K}<t_{j}^{K}$. Under the assumptions of free entry and constant returns to scale, asymmetric tax policies would thus give rise to a market equilibrium with all firms based in the country with the lowest capital tax rate. In other words, parent companies would constitute a perfectly mobile tax base, which would induce countries to engage in cut-throat tax competition. Since this type of interaction reduces comparability with the standard framework and obscures the impact of financial linkages on optimal tax policy, which is the key innovation of the paper, we assume throughout the paper that that firms based in countries $A$ and $B$ have identical financial structures.
} 
where $\tau_{i}$ denotes the effective tax rate on investment in country $i$ given by:

$$
\tau_{i}=\left(1-s_{i}\right) t_{i}^{K}+\left(s_{i}-q\right)\left(z_{i} t_{i}^{K}+z_{j} t_{j}^{K}\right)
$$

The effective tax rate $\tau_{i}$ gives the global tax burden associated with investment in country $i$ given the financial structure $(q, \mathbf{s}, \mathbf{z})$. The first term reflects taxes at the level of the operating subsidiary falling on the part of the investment $\left(1-s_{i}\right)$ financed with equity whereas the second term represents taxes at the level of the finance subsidiaries falling on the part of the investment $\left(s_{i}-q\right)$ financed with internal loans. It is useful to note already at this stage that $\tau_{i}$ depends on the capital tax rates in both countries $i$ and $j$. To highlight this property, we rewrite $\tau_{i}$ in the following way:

$$
\tau_{i}=\alpha_{i i} t_{i}^{K}+\alpha_{i j} t_{j}^{K}
$$

where $\alpha_{i i}$ is the fraction of the capital invested in country $i$, which is taxed in country $i$, and $\alpha_{i j}$ is the fraction of the capital invested in country $i$, which is taxed in country $j$ :

$$
\begin{gathered}
\alpha_{i i} \equiv\left(1-s_{i}\right)+\left(s_{i}-q\right) z_{i} \\
\alpha_{i j}=\left(s_{i}-q\right) z_{j}
\end{gathered}
$$

The fact that operating subsidiaries in country $i$ are partly financed with loans from finance subsidiaries in country $j$ thus implies that countries $i$ and $j$ effectively share the capital tax base generated by operating subsidiaries in country $i$. It should be noted that $\alpha_{i i}+\alpha_{i j}=(1-q)$, which reflects that a fraction $q$ of the capital stock is effectively untaxed. This corresponds to the usual tax advantage of external debt financing when interest expenses are deductible from the corporate tax base and the corresponding interest income is not effectively taxed at the investor level.

We define the capital-labor ratio $k \equiv K / L$ and the function $f(k) \equiv F(k, 1)$. Using these definitions and the assumption of constant returns to scale in the production technology, we restate the profit maximization problem of the firm in the following way:

$$
\max _{L_{A}, L_{B}, k_{A}, k_{B}} \pi=\sum_{i=A, B} L_{i}\left\{f\left(k_{i}\right)-w_{i}-k_{i}\left(r+\tau_{i}\right)\right\}
$$

The first-order conditions for profit-maximization with respect to $k_{i}$ and $L_{i}$ read:

$$
\begin{gathered}
\mathrm{FOC}_{k_{i}}: f^{\prime}\left(k_{i}\right)=r+\tau_{i} \\
\mathrm{FOC}_{L_{i}}: f\left(k_{i}\right)-w_{i}-k_{i}\left(r+\tau_{i}\right)=0
\end{gathered}
$$

Equation (4) implicitly defines the optimal capital-labor ratio $k_{i}^{*}$ as a decreasing function of the cost of capital $r+\tau_{i}$ and may thus be interpreted as a capital demand function. Equation (5) determines the equilibrium wage rate $w_{i}^{*}$ for a given optimal capital-labor ratio $k_{i}^{*}$ :

$$
w_{i}^{*}=f\left(k_{i}^{*}\right)-k_{i}^{*}\left(r+\tau_{i}\right)
$$

It is easy to see that any wage rate higher (lower) than $w_{i}^{*}$ would induce firms to contract (expand) the scale of their operations infinitely, hence $w_{i}^{*}$ is the unique wage rate compatible with equilibrium. Equation (6) may thus be interpreted as (the inverse of) the labor demand function. 
The representative agent in country $i$ maximizes utility by choosing the optimal labor supply given the wage rate $w_{i}$, the tax rate on labor $t_{i}^{L}$, public expenditure $G_{i}$ and non-labor income $r \bar{S}$. The first-order condition states:

$$
U_{X_{i}}=\left(w_{i}-t_{i}^{L}\right) U_{C_{i}}
$$

Equation (7) implicitly determines the labor supply. We impose throughout the paper that the labor supply is positively related to the net-of-tax wage $\left(w_{i}-t_{i}^{L}\right)$. Together $(6)$ and (7) determine the labor market equilibrium $\left(w_{i}^{*}, L_{i}^{*}\right)$. The equilibrium capital stock $K_{i}^{*}$ follows directly from $k_{i}^{*}$ and $L_{i}^{*}$ giving rise to the capital market equilibrium $\left(r, K_{i}^{*}\right)$.

\subsection{Optimal tax policy}

We now turn to the first stage of the game and determination of optimal policy. The government in country $i$ maximizes $U\left(C_{i}, X_{i}, G_{i}\right)$ while correctly anticipating how capital and labor market outcomes respond to taxes. Private consumption and public expenditure are given by the following expressions:

$$
\begin{gathered}
C_{i}=L_{i}^{*}\left(w_{i}^{*}-t_{i}^{L}\right)+\bar{S} r \\
G_{i}=L_{i}^{*} t_{i}^{L}+\alpha_{i i} K_{i}^{*} t_{i}^{K}+\alpha_{j i} K_{j}^{*} t_{i}^{K}
\end{gathered}
$$

It should be noted that the last term of $G_{i}$ represents a link between investment in country $j$ and government revenue in country $i$ since the tax base in country $i$ includes loans from finance subsidiaries in country $i$ to operating subsidiaries in country $j$.

Before solving the government problem, it is useful to see how the equilibrium wage rate is related to tax policy and we therefore differentiate $w_{i}^{*}$ with respect to tax rates $t_{i}^{K}, t_{j}^{K}, t_{i}^{L}$ and $t_{j}^{L}$ :

$$
d w_{i}^{*}=-k_{i}^{*}\left(\alpha_{i i} d t_{i}^{K}+\alpha_{i j} d t_{j}^{K}\right)
$$

This equation is key to our model. Firstly, it shows that labor taxes have no bearing on the equilibrium wage rate, hence suppliers of labor bear the full burden of labor taxes. Secondly, it shows that the equilibrium wage rate in country $i$ is negatively related to the capital tax rate in country $j$ thus exposing the channel through which tax exporting occurs in the model. Due to the intra-firm financial linkages, higher capital taxes in country $j$ raises the effective tax rate on capital employed in country $i$. The full burden of capital taxes is shifted to suppliers of labor through a decline in the equilibrium wage rate, hence a part of the burden of capital taxes in country $j$ is exported to workers in country $i$.

To ease comparison with previous work, we first consider the special case where $s_{A}=s_{B}=q=0$ corresponding to the assumptions of the standard model where firms are completely equity financed both internally and externally. In this special case, we have $\alpha_{i i}=1$ and $\alpha_{j i}=0$, hence there are no intra-firm financial linkages and the scope for tax exporting is effectively eliminated. Inserting (8) and (9) into the utility function and using (10) and (7), we derive the following first-order conditions for maximization of $U\left(C_{i}, X_{i}, G_{i}\right)$ with respect to the labor tax rate $t_{i}^{L}$ and the capital tax rate $t_{i}^{K}$ respectively:

$$
\left.\mathrm{FOC}_{t_{i}^{L}}: U_{G}\left\{1+\varepsilon_{i}^{L}+\varepsilon_{i}^{L} k_{i}^{*} \frac{t_{i}^{K}}{t_{i}^{L}}\right)\right\}-U_{C}=0
$$




$$
\mathrm{FOC}_{t_{i}^{K}}: U_{G}\left\{1+\varepsilon_{i}^{L}+\varepsilon_{i}^{L} k_{i}^{*} \frac{t_{i}^{K}}{t_{i}^{L}}+\varepsilon_{i}^{k}\right\}-U_{C}=0
$$

where $\varepsilon_{i}^{L}$ is the elasticity of the labor supply $L_{i}^{*}$ with respect to the labor tax rate $t_{i}^{L}$ and $\varepsilon_{i}^{k}$ is the elasticity of the capital-labor ratio $k_{i}^{*}$ with respect to the effective capital tax rate $\tau_{i}$, which in this special case equals $t_{i}^{K}$. It is easy to see that (11) and (12) require that $\varepsilon_{i}^{K}=0$, which only holds when $t_{i}^{K}=0$. We summarize this result in the following proposition:

Proposition 1 When firms are fully equity-financed both internally and externally $\left(s_{A}=s_{B}=q=0\right)$ the optimal tax rate on capital tax is zero.

This proposition restates the result derived by Gordon (1986) as a special case where firms are fully equity-financed. ${ }^{7}$ It is instructive to inspect the first-order conditions in more detail. The expressions in curly brackets in (11) and (12) capture the inverse marginal cost of public funds for each of the two tax instruments, that is the amount of public revenue raised with the labor tax and the capital tax respectively for each unit of private consumption foregone. For $t_{i}^{L}$, the marginal deadweight loss has two terms, both related to labor supply responses and thus proportional to the tax elasticity of the labor supply. The first term $\varepsilon_{i}^{L}$ represents changes in the labor tax revenue whereas the second term $\varepsilon_{i}^{L} k_{i}^{*} t_{i}^{K} / t_{i}^{L}$ represents changes in the capital tax revenue. The latter effect owes itself to the fact that changes in the labor supply $L_{i}^{*}$ produce proportional changes in the capital tax base $K_{i}^{*}$ for a given capital-labor ratio $k_{i}^{*}$. For $t_{i}^{K}$, the marginal deadweight loss has the same two terms and an additional term $\varepsilon_{i}^{k}$. The first two terms reflect that capital taxes reduce the net-of-tax wage $\left(w_{i}^{*}-t_{i}^{L}\right)$ by exactly the same amount as labor taxes per dollar of revenue raised where capital taxes work through changes in the gross wage rate $w_{i}^{*}$. The third term captures the distortion of the capital-labor ratio introduced by the capital tax. It follows directly that labor taxes raise more revenue than capital taxes per unit of private consumption foregone and that capital taxes should therefore not be employed. In brief, capital taxes distort the labor supply to the same extent as labor taxes and moreover distort the capital-labor ratio of firms, hence they are inferior to labor taxes.

We now turn to the more general case where multinational firms have a fixed financial structure with $s_{i} \geq q \geq 0$. Inserting (8) and (9) into the utility function and using (10) and (7), it is straightforward to show that the first-order conditions for maximization of $U\left(C_{i}, X_{i}, G_{i}\right)$ with respect to the labor tax rate $t_{i}^{L}$ and the capital tax rate $t_{i}^{K}$ are:

$$
\mathrm{FOC}_{t_{i}^{L}}: U_{G}\left\{1+\varepsilon_{i}^{L}+\varepsilon_{i}^{L} \alpha_{i i} k_{i}^{*} \frac{t_{i}^{K}}{t_{i}^{L}}\right\}-U_{C}=0
$$

$$
\mathrm{FOC}_{t_{i}^{K}}: U_{G}\left\{1+\varepsilon_{i}^{L}+\varepsilon_{i}^{L} \alpha_{i i} k_{i}^{*} \frac{t_{i}^{K}}{t_{i}^{L}}+\varepsilon_{i}^{k} \alpha_{i i} \frac{t_{i}^{K}}{\tau_{i}}+\frac{\alpha_{j i}}{\alpha_{i i}} \frac{K_{j}^{*}}{K_{i}^{*}}+\frac{\alpha_{j i}^{2}}{\alpha_{i i}} \frac{K_{j}^{*}}{K_{i}^{*}}\left(\varepsilon_{j}^{L} \frac{t_{i}^{K}}{t_{j}^{L}} k_{j}^{*}+\varepsilon_{j}^{k} \frac{t_{i}^{K}}{\tau_{j}}\right)\right\}-U_{C}=0
$$

\footnotetext{
${ }^{7}$ Proposition 1 may easily be generalized to any set of parameters $s_{A}=s_{B}=q \geq 0$ where operating subsidiaries are partly financed with a positive fraction of external debt and zero internal debt.
} 
As before, the expressions in curly brackets express the inverse marginal cost of public funds. For $t_{i}^{L}$, the marginal cost of public funds is identical to the case of fully equity-financed firms except for the factor $\alpha_{i i}$ on the last term, which reflects that behavioral responses reducing the capital stock $K_{i}^{*}$ (i.e. reductions in $L_{i}^{*}$ or $k_{i}^{*}$ ) now have a smaller revenue effect since only a fraction $\alpha_{i i}$ of $K_{i}^{*}$ is effectively taxed in country $i$. For $t_{i}^{K}$, the marginal cost of public funds includes the same terms as for $t_{i}^{L}$ and four additional terms. We consider these terms in turn: The first term $\varepsilon_{i}^{k} \alpha_{i i} t_{i}^{K} / \tau_{i}$ is the equivalent of the last term in (4) and captures the marginal deadweight loss associated with distortions of the capital-labor ratio $k_{i}^{*}$. The second term $\alpha_{j i} K_{j}^{*} / \alpha_{i i} K_{i}^{*}$ is the tax exporting effect, which reflects that capital taxes in country $i$ are partly borne by workers in country $j$. Intuitively, the tax exporting effect is increasing in the foreign capital stock effectively subject to domestic capital taxation $\alpha_{j i} K_{j}^{*}$ and decreasing in the domestic capital stock effectively subject to domestic capital taxation $\alpha_{i i} K_{i}^{*}$. The final two terms capture behavioral responses in country $j$ that erode capital tax revenues in country $i$. Intuitively, capital taxes in country $i$ raise effective capital taxation in country $j$ and thus lower the capital stock $K_{j}^{*}$, which is partly subject to taxation in country $i$, through reductions in both $L_{j}^{*}$ and $k_{j}^{*}$.

Equations (13) and (14) imply that an optimal tax mix in country $i$ must satisfy the following equation:

$$
\varepsilon_{i}^{k} \alpha_{i i} \frac{t_{i}^{K}}{\tau_{i}}+\frac{\alpha_{j i}}{\alpha_{i i}} \frac{K_{j}^{*}}{K_{i}^{*}}+\frac{\alpha_{j i}^{2}}{\alpha_{i i}} \frac{K_{j}^{*}}{K_{i}^{*}}\left(\varepsilon_{j}^{L} \frac{t_{i}^{K}}{t_{j}^{L}} k_{j}^{*}+\varepsilon_{j}^{k} \frac{t_{i}^{K}}{\tau_{j}}\right)=0
$$

It is easy to verify that $\alpha_{j i} K_{j} / \alpha_{i i} K_{i}$ is positive whereas all other terms are proportional to $-t_{i}^{K}$. It follows that only a tax vector $\left(t_{i}^{K}, t_{i}^{L}\right)$ with $t_{i}^{K}>0$ can satisfy equations (13) and (14). We summarize this result in the following proposition:

Proposition 2 When firms have a fixed financial structure involving some internal debt financing $\left(s_{i}>\right.$ q) and some diversification of financial assets $\left(0<z_{i}<1\right)$, the optimal capital tax rate is strictly positive.

The result reported in proposition 2 is driven by tax exporting. Capital taxes in country $i$ raise the cost of capital in both countries $i$ and $j$ and part of the tax burden is therefore borne by workers in country $j$ through a reduction in $w_{j}^{*}$. Capital taxes still have the undesirable effect of distorting the capital-labor ratio in countries $i$ and $j$, however, the marginal deadweight loss is zero when evaluated at

$t_{i}^{K}=0$. Intuitively, the marginal deadweight loss associated with an increase in $t_{i}^{K}$ equals the marginal revenue loss due to behavioral responses and starting from a policy vector with $t_{i}^{K}=0$, the marginal revenue loss caused by an erosion of the capital tax base is zero.

\section{An extended model with endogenous capital structure}

\subsection{Further assumptions}

The purpose of this section is to show that proposition 2, which was derived under the assumption of a fixed financial structure, extends to a more realistic setting where the financial structure responds to changes in the tax environment. Instead of explicitly modelling the multitude of determinants of the 
optimal capital structure, we adopt the following reduced form specification: A target capital structure $(\widetilde{q}, \widetilde{\mathbf{s}}, \widetilde{\mathbf{z}})$ represents the optimal capital structure absent tax considerations and tax motivated deviations from the target capital structure are associated with real costs. Firms make optimal choices in the three dimensions of the financial structure and thus choose: (i) $q$ and incur a cost proportional to $g(q)$ where $g(\widetilde{q})=0, g^{\prime}(q)(q-\widetilde{q}) \geq 0$ and $g^{\prime \prime}(q) \geq 0$ implying that costs are (weakly) convex in the distance $|q-\widetilde{q}| ;\left(\right.$ ii) $\left(s_{A} ; s_{B}\right)$ and incur costs proportional to $b\left(s_{i}\right)$ where $b(\widetilde{s})=0, b^{\prime}\left(s_{i}\right)\left(s_{i}-\widetilde{s}\right) \geq 0$ and $b^{\prime \prime}\left(s_{i}\right) \geq 0$ implying that costs are (weakly) convex in the distance $\left|s_{i}-\widetilde{s}\right|$; (iii) $\left(z_{A} ; z_{B}\right)$ and incur costs proportional to $h\left(z_{i}\right)$ where $h_{i}\left(\widetilde{z_{i}}\right)=0, h_{i}^{\prime}\left(z_{i}\right)\left(z_{i}-\widetilde{z_{i}}\right) \geq 0$ and $h_{i}^{\prime \prime}\left(z_{i}\right) \geq 0$ implying that costs are (weakly) convex in the distance $\left|z_{i}-\widetilde{z_{i}}\right|$. Moreover, we assume that costs related to $q$ are proportional to the total capital stock of the firm, costs related to $s_{i}$ are proportional to the capital stock in country $i$ and costs related to $z$ are proportional to the size of intra-firm loans. These specifications seem reasonable and ensure that constant returns to scale is retained. Finally, cost functions are scaled so that costs are expressed in units of output.

It is useful to briefly lay out mechanisms that support this reduced form. Starting with $q$, it is a standard presumption in the corporate finance literature that leverage is associated with non-tax costs in terms of a higher probability of costly bankruptcy procedures and suboptimal risk-taking. This assumption implies that $\widetilde{q}=0$, however, we adopt a slightly more general specification by assuming that $\widetilde{q} \geq 0$. Turning to $\mathbf{s}$, it was suggested in section 2 that agency problems at the level of the operating subsidiaries may be alleviated by debt. We thus assume that $\widetilde{s_{i}}>\widetilde{q}$ reflecting that agency problems are sufficiently strong to ensure that the target leverage at the operating subsidiary level exceeds the target leverage at the firm level. Finally, we assume that $0<\widetilde{z_{i}}<1$ implying that the target capital structure involves some diversification of financial assets on entities in different countries. This would be true if the cost of capital raised in external capital markets to finance operating subsidiaries in country $i$ depends on the consolidated leverage of affiliates in country $i$ (i.e. the asset-weighted average leverage of operating and finance subsidiaries in country $i$ ), for instance, because foreign assets are more costly to seize than domestic assets in the event of bankruptcy.

The structure of the game analyzed in this section closely follows the game analyzed in section 3 except that firms choose the optimal financial structure $\left(q^{*}, \mathbf{s}^{*}, \mathbf{z}^{*}\right)$ simultaneously with the optimal capital and labor inputs. Section 4.2 characterizes the labor and capital market equilibria for given policies whereas section 4.3 derives conditions for optimal policies.

\subsection{Capital and labor market equilibrium}

With the additional assumptions introduced in the previous subsection, the profit function of the multinational firm may be stated as follows:

$$
\begin{aligned}
\pi= & \sum_{i=A, B}\left\{F\left(K_{i}, L_{i}\right)-L_{i} w_{i}-\left(r+\tau_{i}\right) K_{i}\right\} \\
& -b\left(s_{A}\right) K_{A}-b\left(s_{B}\right) K_{B}-g(q)\left\{K_{A}+K_{B}\right\}-\left\{h\left(z_{A}\right)+h\left(z_{B}\right)\right\}\left\{\left(s_{A}-q\right) K_{A}+\left(s_{B}-q\right) K_{B}\right\}
\end{aligned}
$$


The first line reiterates the profit function of the basic model. The second line summarizes the cost terms associated with the debt-asset ratios at the operating subsidiary level $s_{i}$, the debt-asset ratio at the firm level $q$ and the distribution of financial assets $z_{i}$. Profits are maximized over capital and labor inputs in each of the two operating subsidiaries as well as the five dimensions of the financial structure.

The profit maximization problem is solved in the Appendix. The properties of the optimal financial structure may be summarized as follows: (i) $q^{*}>\widetilde{q}$ except when $t_{i}^{K}=t_{j}^{K}=0$ in which case $q^{*}=\widetilde{q}$. These properties derive from the tax advantage of external debt over equity, which vanishes as corporate tax rates are approaching zero; (ii) $s_{i}^{*}>\widetilde{s}_{i}$ is possible only if $t_{i}^{K}>t_{j}^{K}$. Intuitively, financing the subsidiary in country $i$ with intra-firm debt involves some shifting of tax base from country $i$ to country $j$; (iii) $z_{i}^{*}>\widetilde{z_{i}}$ if and only if $t_{i}^{K}<t_{j}^{K}$. Moreover, it is shown that changes in the optimal financial structure is related to changes in tax rates in the following intuitive way: $z_{i}^{*}$ increases with $t_{j}^{K}$ and decreases with $t_{i}^{K}, q^{*}$ increases with $t_{i}^{K}$ and $t_{j}^{K}$, and $s_{i}^{*}$ increases with $t_{i}^{K}$ and decreases with $t_{j}^{K}$. This implies that multinational firms respond to a tax increase in country $i$ by adjusting all dimensions of their financial structure with the aim of reducing the tax base in country $i$.

Utility maximization of the representative agent leads to a first-order condition identical to (7), which implicitly defines labor supply as a function of the net-of-tax wage rate. The profit maximization problem gives rise to a uniquely determined equilibrium wage rate:

$$
w_{i}^{*}=f\left(k_{i}^{*}\right)-\left[r+\tau_{i}+b\left(s_{i}^{*}\right)+g\left(q^{*}\right)+\left\{h\left(z_{i}^{*}\right)+h\left(z_{j}^{*}\right)\right\}\left(s_{i}^{*}-q^{*}\right)\right] k_{i}^{*}
$$

Together, the labor supply function and the equilibrium wage rate define the labor market equilibrium $\left(w_{i}^{*}, L_{i}^{*}\right)$. The equilibrium capital stock $K_{i}^{*}$ follows directly from $k_{i}^{*}$ and $L_{i}^{*}$ giving rise to the capital market equilibrium $\left(r, K_{i}^{*}\right)$.

\subsection{Optimal tax policy}

Private consumption and government expenditure are given by (8) and (9) respectively with the single qualification that $\alpha_{i i}$ and $\alpha_{j i}$ are endogenous in the present setting. Differentiating the equilibrium wage rate with respect to $t_{i}^{L}, t_{i}^{K}$ and $t_{j}^{K}$ yields an expression for $d w$, which is identical to (10). Intuitively, firms respond to tax changes with adjustments in the financial structure, however, the effects of the adjustments on profits and wages are second-order since the financial structure is initially optimized. This is an application of the envelope theorem.

Using the expressions for $C_{i}, G_{i}$ and $d w$, we derive the following first-order conditions for maximization of $U\left(C_{i}, X_{i}, G_{i}\right)$ with respect to $t_{i}^{L}$ and $t_{i}^{K}$ respectively:

$$
\begin{gathered}
U_{G}\left\{1+\varepsilon_{i}^{L}+\varepsilon_{i}^{L} \alpha_{i i} k_{i}^{*} \frac{t_{i}^{K}}{t_{i}^{L}}\right\}-U_{C}=0 \\
U_{G}\left\{1+\varepsilon_{i}^{L}+\varepsilon_{i}^{L} \alpha_{i i} k_{i}^{*} \frac{t_{i}^{K}}{t_{i}^{L}}+\varepsilon_{i}^{k} \alpha_{i i} \frac{t_{i}^{K}}{\tau_{i}}+\frac{\alpha_{j i}}{\alpha_{i i}} \frac{K_{j}^{*}}{K_{i}^{*}}+\frac{\alpha_{j i}^{2}}{\alpha_{i i}} \frac{K_{j}^{*}}{K_{i}^{*}}\left(\varepsilon_{j}^{L} \frac{t_{i}^{K}}{t_{j}^{L}} k_{j}^{*}+\varepsilon_{j}^{k} \frac{t_{i}^{K}}{\tau_{j}}\right)+A_{i} t_{i}^{K}\right\}-U_{C}=0
\end{gathered}
$$


where

$$
A \equiv \frac{1}{\alpha_{i i}}\left(\frac{d s_{j}^{*}}{d t_{i}^{K}} \frac{K_{j}^{*}}{K_{i}^{*}} z_{i}^{*}-\frac{d s_{i}^{*}}{d t_{i}^{K}} z_{j}^{*}+\frac{d z_{i}^{*}}{d t_{i}^{K}}\left[\left(s_{i}^{*}-q^{*}\right)+\frac{K_{j}^{*}}{K_{i}^{*}}\left(s_{j}^{*}-q^{*}\right)\right]-\frac{d q^{*}}{d t_{i}^{K}}\left[z_{i}^{*}\left(1+\frac{K_{j}^{*}}{K_{i}^{*}}\right)\right]\right)
$$

Whereas (16) is identical to the equivalent in the simple model, (17) has an additional term $A_{i} t_{i}^{K}$, which represents the revenue effect of the adjustments to the optimal financial structure induced by a marginal increase in $t_{i}^{K}$. We note that $A$ is unambiguously negative, which derives from the fact that multinational firms respond to tax increases in country $i$ by adjusting all dimensions of their financial structure in order to reduce the tax base in country $i$.

It follows from (16) and (17) that the following expression needs to be satisfied by an optimal tax $\operatorname{mix}\left(t_{i}^{L}, t_{i}^{K}\right)$.

$$
\varepsilon_{i}^{k} \alpha_{i i} \frac{t_{i}^{K}}{\tau_{i}}+\frac{\alpha_{j i}}{\alpha_{i i}} \frac{K_{j}^{*}}{K_{i}^{*}}+\frac{\alpha_{j i}^{2}}{\alpha_{i i}} \frac{K_{j}^{*}}{K_{i}^{*}}\left(\varepsilon_{j}^{L} \frac{t_{i}^{K}}{t_{j}^{L}} k_{j}^{*}+\varepsilon_{j}^{k} \frac{t_{i}^{K}}{\tau_{j}}\right)+A_{i} t_{i}^{K}=0
$$

This is the equivalent of (15) and a similar argument applies: Assuming that $A$ is bounded, all terms except $\alpha_{j i} K_{j}^{*} / \alpha_{i i} K_{i}^{*}$ are proportional to $-t_{i}^{K}$, which implies that only a tax vector $\left(t_{i}^{K}, t_{i}^{L}\right)$ with $t_{i}^{K}>0$ can satisfy equations (16) and (17). It may easily be verified using the expressions for $d z_{i}, d q$ and $d s_{i}$ derived in the Appendix that the boundedness of $A$ is ensured if the second-order derivatives of the cost functions $h(\cdot), g(\cdot)$ and $b(\cdot)$ are strictly positive. Essentially, strict convexity of cost functions $h(\cdot), g(\cdot)$ and $b(\cdot)$ implies that the elasticity of all dimensions of the capital structure with respect to taxes is finite so that marginal tax changes induce marginal behavioral responses. We summarize this analysis in the following proposition:

Proposition 3 When firms optimally choose their financial structure, the optimal capital tax rate is strictly positive provided that $h(\cdot), g(\cdot)$ and $b(\cdot)$ are strictly convex functions.

Intuitively, capital taxes in country $i$ trigger adjustments of the financial structure that erode the capital tax base in country $i$, however, evaluated at $t_{i}^{K}=0$, the marginal revenue loss - and thus the marginal deadweight loss - associated with these responses is zero. Since the tax exporting property of capital taxes is still at play, the optimal capital tax rate is strictly positive.

\section{A crude empirical test}

This section investigates the empirical relevance of the model on the basis of the following observations: On one hand, profit maximization implies that firms should allocate less financial assets to jurisdictions with relatively high corporate tax rates. In a cross-country context, this suggests a negative correlation between the amount of interest income earned by firms and the corporate tax rate where causality goes from taxes to interest income. On the other hand, the reasoning underlying the model implies that countries to which firms allocate relatively large amounts of interest income optimally set higher capital tax rates. Intuitively, the tax exporting effect derives from the share of the capital invested in foreign countries that is subject to domestic taxation. This suggests a positive correlation between 
interest income earned by firms and the corporate tax rate where causality goes from interest income to taxes. ${ }^{8}$ As a crude test of the empirical relevance of the model, we thus estimate the empirical correlation between the interest income component of corporate profits and corporate tax rates across countries. If the tax exporting mechanism highlighted in this paper is insignificant, we should expect that the negative correlation deriving from the profit maximizing behavior of firms dominates. If the tax exporting mechanism is sufficiently strong, we should expect that the positive correlation deriving from governments exploiting the potential for tax exporting dominates.

We estimate the empirical correlation between the share of interest income in corporate profits and corporate tax rates for a sample of 27 European countries using sectoral account data collected by Eurostat, the official statistical bureau of the European Union. An important merit of this sample is that the common data source ensures that measures are comparable across countries. The sectoral account data include a direct measure of gross interest income in the non-financial corporate sector. ${ }^{9}$ As a measure of corporate profits, we use 'gross operating surplus', defined as total output less the cost of labor inputs and intermediate goods and services, in the non-financial corporate sector. ${ }^{10}$ Finally, we use statutory corporate tax rates combining federal and local taxes reported by ZEW (2008) as a measure of the corporate tax level. ${ }^{11}$

Figure 3 plots corporate tax rates against the ratio of interest income to gross operating surplus in non-financial corporations in 2007. There is considerable cross-country variation in both variables with the interest income component in corporate profits ranging from 0.02 (Lithuania) to 0.29 (Sweden) and corporate tax rates ranging from 0.1 (Bulgaria and Cyprus) to 0.39 (Germany). As indicated by the estimated trend line, the correlation between the two variables is moderately positive, which is consistent with the hypothesis that countries exploit the tax exporting potential introduced by internal capital markets within multinational firms. We emphasize, however, that the estimated coefficients reported in the figure should not be interpreted as an estimate of the causal effect. Clearly, this simple empirical framework suffers from issues of reverse causality and omitted variables that make it unsuitable for providing reliable estimates of causal effects.

\footnotetext{
${ }^{8} \mathrm{~A}$ formal derivation of this result would require an analysis of the equilibrium of an asymmetric model where $\alpha_{i j} \neq \alpha_{j i}$. This is beyond the scope of this paper.

${ }^{9}$ Ideally this measure would be refined to include only interest payments from foreign affiliates since interest income from other sources (e.g. bank deposits and domestic affiliates) do not create a scope for tax exporting, however, the dataset does not provide a decomposition on the source of the interest income.

${ }^{10}$ Arguably, 'net operating surplus', which excludes consumption of fixed capital, would be a better measure of profits, however, this income category is only reported by a subset of countries.

${ }^{11}$ While the statutory corporate tax rate is typically the effective tax rate applying to the interest income earned by corporations, there are exceptions to this principle: Loss-making firms face a lower effective tax rate on interest income if (i) there is imperfect carry-forward of tax losses or (ii) there is a positive probability that the firm will never make enough profits to use the tax losses. Moreover, some countries maintain special tax regimes that reduce the effective taxation of internationally mobile financial income.
} 


\section{Concluding remarks}

This paper has developed a model of corporate taxation in the presence of financially integrated multinational firms. The two key assumptions of the model - and the main departure from standard models of international taxation - relate to the internal capital markets of multinational firms. Specifically, it was assumed that multinational firms partly finance foreign investment with internal loans and that internal loans are not entirely driven by a profit shifting motive. The main finding is that the presence of internal loans introduces a tax exporting motive for corporate taxes. Intuitively, to the extent that multinational firms finance investment in country $i$ with loans from affiliates in country $j$, the burden of corporate taxes in the latter country partly fall on investment and thus workers in the former country. Our model thus represents a way to resolve the tension between the standard result that the optimal source based capital tax is zero and the casual observation that most countries employ corporate taxes at non-negligible rates.

In general terms, the analysis suggests that drawing on the sophisticated theories of the firm developed in recent decades may lead to important new insights in the field of international taxation. It is striking that most models of taxation make highly simplistic assumptions about firm behavior and largely ignore interactions and transactions taking place within the boundaries of the firm. Embedding a more elaborate modelling of the firm in theories of capital taxation thus appears to be a promising avenue for further research.

\section{References}

Altshuler, R., Grubert, H., 2002. Repatriation Taxes, Repatriation Strategies and Multinational Financial Policy. Journal of Public Economics 87, 73-107.

Buettner, T., Overesch, M., Schreiber, U., Wamser, G., 2009. Taxation and Capital Structure Choice

- Evidence from a Panel of German Multinationals. Economics Letters 105(3), 309-311.

Buettner, T., Wamser, G., 2009. Internal Debt and Multinationals' Profit Shifting - Empirical Evidence from Firm-Level Panel Data. Working Paper 09/18. Oxford University Centre for Business Taxation.

Chowdry, B., Coval, J., 1998. Internal Financing of Multinational Subsidiaries: Debt vs. Equity. Journal of Corporate Finance 4, 87-106.

Desai, M.A., Foley, F., Forbes, K.J., 2007. Financial Constraints and Growth: Multinational and Local Firm Responses to Currency Depreciations. Review of Financial Studies 21(6), 2857-2888.

Desai, M.A., Foley, F., Hines, J.R., 2004. A Multinational Perspective on Capital Structure Choice and Internal Capital Markets. Journal of Finance 59(6), 2451-2488.

European Commission, 2006. Proposal for a Council Directive Concerning Indirect Taxes on the Raising of Capital. $\operatorname{COM}(2006) 760$ final.

Fuest, C., Hemmelgarn, T, 2005. Corporate Tax Policy, Foreign Firm Ownership and Thin Capital- 
ization. Regional Science and Urban Economics 35, 508-526.

Gopalan, R., Nanda, V., Seru, A., 2007. Affiliated Firms and Financial Support: Evidence from Indian Business Groups. Journal of Financial Economics 86, 759-785.

Gordon, R., 1986. Taxation of investment and savings in a world economy. American Economic Review 76, 1086-1102.

Gordon, R., MacKie-Mason, J. K., 1994. Why Is There Corporate Taxation In a Small Open Economy? The Role of Transfer Pricing and Income Shifting. NBER Working Papers, 4690.

Gordon, R., Varian, H. R., 1989, Taxation of Asset Income in the Presence of a World Securities Market. Journal of International Economics 26, 205-226.

Huizinga, H., Laeven, L., Nicodeme, G., 2008. Capital structure and international debt shifting. Journal of Financial Economics 88, 80-118.

Huizinga, H., Nielsen, S.B., 1997. Capital income and profit taxation with foreign ownership of firms. Journal of International Economics 42, 149-165.

Jensen, M.C., 1986. Agency Costs of Free Cash Flow, Corporate Finance and Takeovers. American Economic Review 76(2), 323-329.

Johannesen, N., 2010. Optimal Fiscal Barriers to International Economic Integration in the Presence of Tax Havens. Unpublished paper. University of Copenhagen.

Ramb, F., Weichenreider, A.J., 2005. Taxes and the Financial Structure of German Inward FDI. Review of World Economics 141(4), 670-692.

Wildasin, D.E., 2003. Fiscal competition in time and space. Journal of Public Economics 87, 25712588 .

ZEW (Zentrum für Europäische Wirtschaftsforschung), 2008. Effective Levels of Company Taxation within an Enlarged European Union. Project for the European Commission TAXUD/2005/DE/3 10.

\section{Appendix}

Analogously to the simple model, we rewrite the profit function in the following way:

$$
\pi=\sum_{i=A, B} L_{i}\left\{f\left(k_{i}\right)-w_{i}-\left[r+\tau_{i}+b\left(s_{i}\right)+g(q)+\left\{h\left(z_{A}\right)+h\left(z_{B}\right)\right\}\left(s_{i}-q\right)\right] k_{i}\right\}
$$

Multinational firms maximize $\pi$ over $z_{i}, q, s_{i}, k_{i}$ and $L_{i}$ for $i=A, B$ and we state the first-order conditions below:

$$
\begin{gathered}
\mathrm{FOC}_{z_{i}}: h^{\prime}\left(z_{j}\right)-h^{\prime}\left(z_{i}\right)=t_{i}^{K}-t_{j}^{K} \\
\mathrm{FOC}_{q}: g^{\prime}(q)=z_{i} t_{i}^{K}+z_{j} t_{j}^{K}+h\left(z_{i}\right)+h\left(z_{j}\right) \\
\mathrm{FOC}_{s_{i}}: b^{\prime}\left(s_{i}\right)=\left(1-z_{i}\right)\left\{t_{i}^{K}-t_{j}^{K}\right\}-h\left(z_{i}\right)-h\left(z_{j}\right) \\
\mathrm{FOC}_{k_{i}}: f^{\prime}\left(k_{i}\right)=r+\tau_{i}+b\left(s_{i}\right)+g(q)+\left\{h\left(z_{A}\right)+h\left(z_{A}\right)\right\}\left(s_{i}-q\right) \\
\mathrm{FOC}_{L_{i}}: f\left(k_{i}\right)-w_{i}-f^{\prime}\left(k_{i}\right) k_{i}=0
\end{gathered}
$$


where it should be noted that the identity $z_{A}+z_{B}=1$ implies that the choice $\left(z_{A} ; z_{B}\right)$ is effectively one-dimensional. The set of first-order conditions can be solved sequentially: The optimal distribution of financial assets $z_{A}^{*}$ and $z_{B}^{*}$ is uniquely determined by (18). Conditional on $\left(z_{A}^{*} ; z_{B}^{*}\right)$, the optimal leverage ratio of the firm as a whole $q^{*}$ is determined by (19) and the optimal leverage of each operating subsidiary $s_{A}^{*}$ and $s_{B}^{*}$ are determined by (20). Conditional on the optimal financial structure of the firm, the optimal capital-labor ratios $k_{A}^{*}$ and $k_{B}^{*}$ are determined by (21). Finally, (22) determines the equilibrium wage rate $w_{i}^{*}$ :

$$
w_{i}^{*}=f\left(k_{i}^{*}\right)-\left[r+\tau_{i}+b\left(s_{i}^{*}\right)+g\left(q^{*}\right)+\left\{h\left(z_{i}^{*}\right)+h\left(z_{j}^{*}\right)\right\}\left(s_{i}^{*}-q^{*}\right)\right] k_{i}^{*}
$$

where we have used (21). Differentiating (18)-(20) and assuming interior solutions, it is easy to show that the optimal financial structure responds to tax changes in the following way:

$$
\begin{aligned}
d z_{i}^{*} & =\frac{d t_{j}^{K}-d t_{i}^{K}}{h^{\prime \prime}\left(z_{i}^{*}\right)+h^{\prime \prime}\left(z_{j}^{*}\right)} \\
d q^{*} & =\frac{z_{i}^{*} d t_{i}^{K}+z_{j}^{*} d t_{j}^{K}}{g^{\prime \prime}\left(q^{*}\right)} \\
d s_{i}^{*} & =\frac{z_{j}^{*}\left(d t_{i}^{K}-d t_{j}^{K}\right)}{b^{\prime \prime}\left(s_{i}^{*}\right)}
\end{aligned}
$$




\begin{tabular}{|c|c|c|c|c|}
\hline & Buettner and Wamser (2009) & Ramb and Weichenreider (2005) & Desai et al (2004) & Altshuler and Grubert (2003) \\
\hline Data source & Bundesbank & Bundesbank & BEA survey & Interna I Revenue \\
\hline Sample & Foreign affiliates of German firms & German affiliates of non-German firms & Foreign affiliates of US firms & Foreign affiliates of US firms \\
\hline Year & 1996-2005 & $2001^{*}$ & 1994 & 1996 \\
\hline Total debt- asset ratio & 0.586 & 0.529 & 0.545 & 0.539 \\
\hline Internal debt -asset ratio & 0.241 & 0.296 & - & - \\
\hline - from parent company & 0.135 & - & 0.085 & 0.110 \\
\hline - from other affiliates & 0.106 & - & - & - \\
\hline
\end{tabular}


Figure 1: Debt versus equity financing with chains of ownership

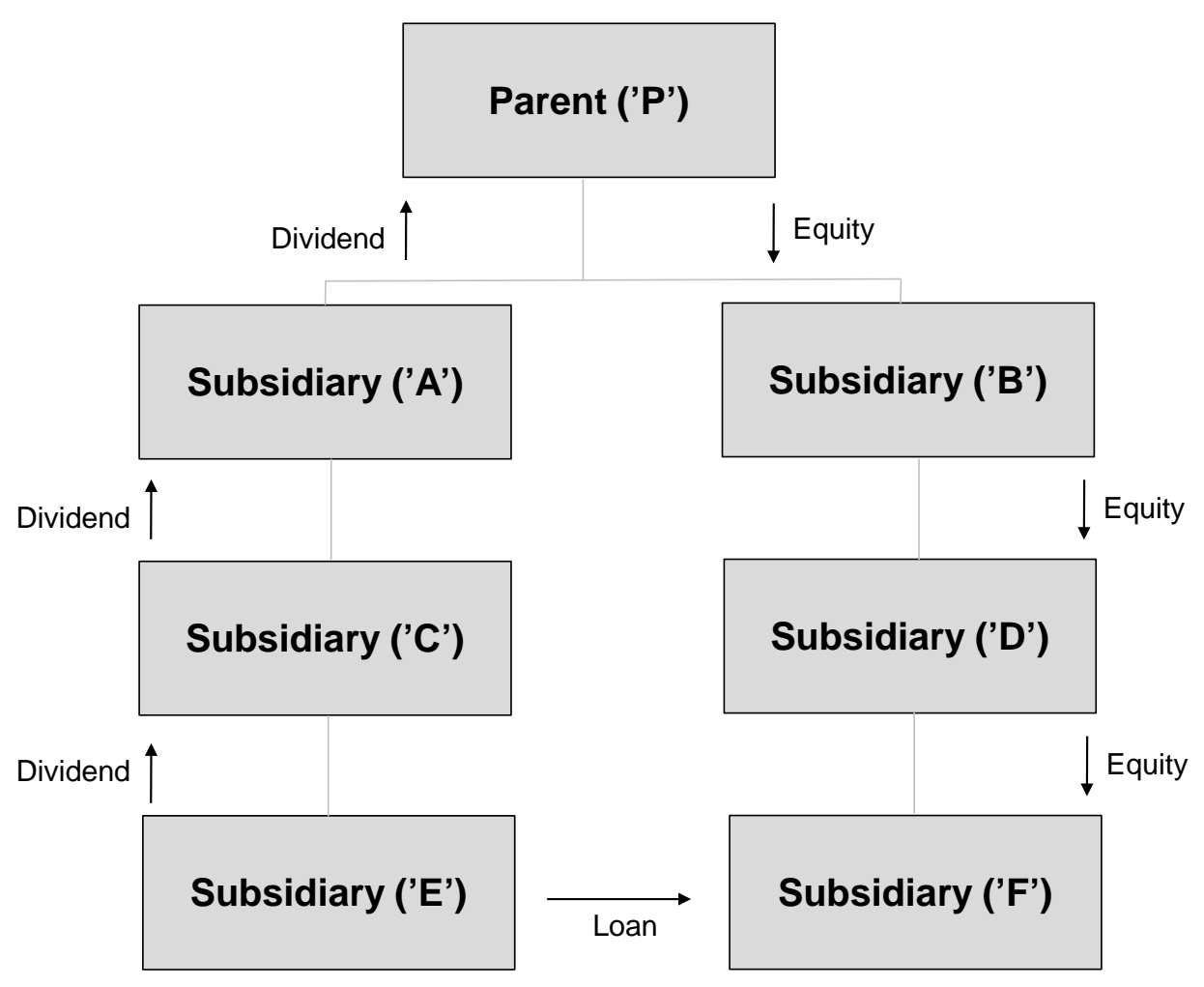


Figure 2: The capital structure of the multinational firm

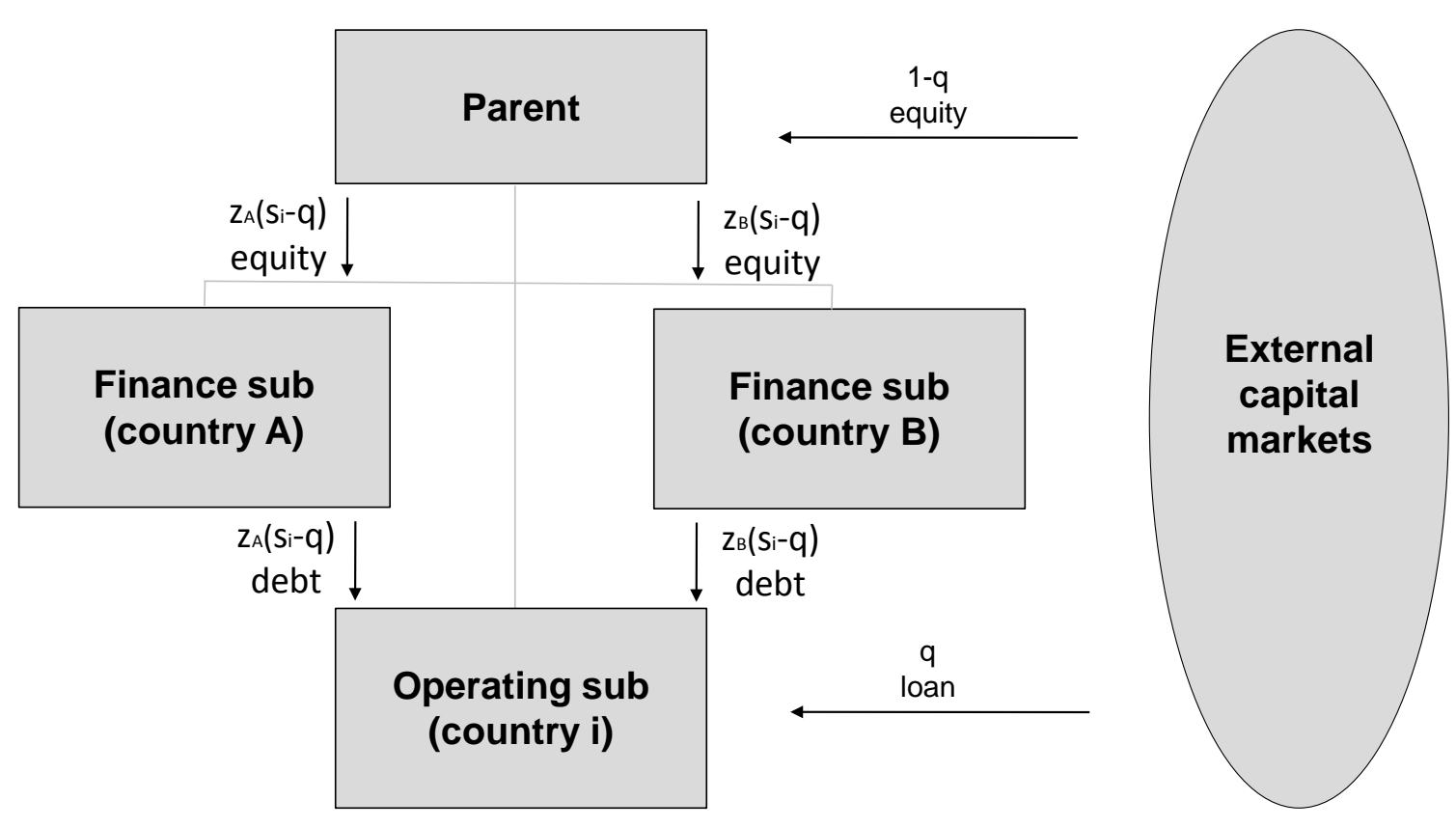


Figure 3: A crude empirical test

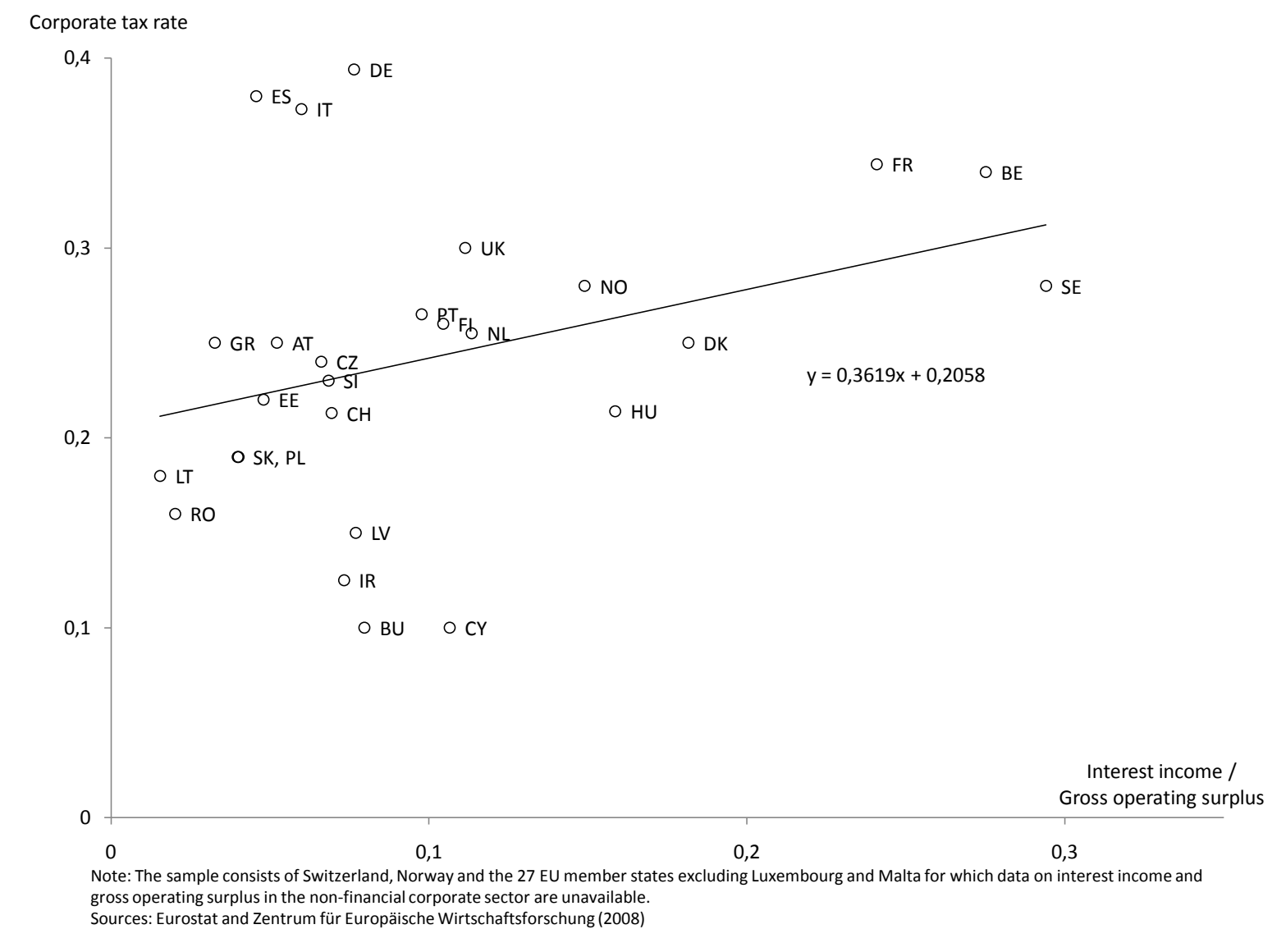

